DEMOGRAPHIC RESEARCH

VOLUME 35, ARTICLE 13, PAGES 339-380 PUBLISHED 18 AUGUST 2016

http://www.demographic-research.org/Volumes/Vol35/13/

DOI: 10.4054/DemRes.2016.35.13

Research Article

\title{
What drives Senegalese migration to Europe? The role of economic restructuring, labor demand, and the multiplier effect of networks
}

\section{Pau Baizán}

\section{Amparo González-Ferrer}

(C) 2016 Pau Baizán \& Amparo González-Ferrer.

This open-access work is published under the terms of the Creative Commons Attribution NonCommercial License 2.0 Germany, which permits use, reproduction \& distribution in any medium for non-commercial purposes, provided the original author(s) and source are given credit.

See http:// creativecommons.org/licenses/by-nc/2.0/de/ 


\section{Contents}

$\begin{array}{lll}1 & \text { Introduction } & 340\end{array}$

2 The surge of Senegalese migration to Europe 342

$3 \quad$ Linking theories with context 343

$3.1 \quad$ Migration as a response to increased economic insecurity 343

3.2 New employment opportunities in Europe 347

3.3 Personal resources and the viability of migration as a strategy 348

3.4 The interaction between social capital and labor demand 350

$4 \quad$ Data and variables 352

5 Methods 357

6 Results 359

6.1 Life course and family variables $\quad 361$

6.2 Economic Insecurity Hypothesis 364

6.3 Social Capital Hypothesis 366

6.4 Labor Demand Hypothesis 366

6.5 Hypothesis of Interaction between Labor Demand and Social 367

Capital

7 Conclusions 368

$8 \quad$ Acknowledgments 370

$\begin{array}{ll}\text { References } & 371\end{array}$ 


\title{
What drives Senegalese migration to Europe? The role of economic restructuring, labor demand, and the multiplier effect of networks
}

\author{
Pau Baizán ${ }^{1}$ \\ Amparo González-Ferrer ${ }^{2}$
}

\begin{abstract}

\section{BACKGROUND}

International migration from Sub-Saharan Africa to Europe is poorly understood. Furthermore, existing studies pay insufficient attention to the links between the microlevel factors and political, social, and economic processes in both origin and destination areas. Here we integrate insights from institutional approaches in migration and development research with perspectives that highlight the role of labor market and social capital.
\end{abstract}

\section{OBJECTIVE}

We analyze the contextual and individual-level determinants of migration from Senegal to France, Italy, and Spain since the mid-1970s. We examine the following hypotheses: (1) In Senegal, the deterioration of living conditions and heightened economic insecurity have created the conditions for increasing out-migration propensities. (2) In Europe, labor market restructuring has increased job opportunities in particular places and job niches. (3) In facilitating access of Senegalese migrants to jobs in Europe, social networks have linked these two processes. (4) The conjunction of periods of strong labor demand and the availability of personal networks in Europe creates a boosting effect on the migration probabilities of the Senegalese to Europe.

\section{METHODS}

We use event history models to analyze life course data from the Migrations between Africa and Europe survey (2008).

\section{RESULTS}

Our empirical results concerning both individual socioeconomic indicators and contextual indicators provide consistent support for the four hypotheses proposed.

\footnotetext{
${ }^{1}$ Universitat Pompeu Fabra, Ramon Trias Fargas 25, 08005 Barcelona, Spain. 2 ICREA, Pg. Lluís Companys 23, 08010 Barcelona, Spain.E-Mail: pau.baizan@upf.edu.

${ }^{2}$ Spanish Council for Scientific Research (CSIC), Spain.
} 


\section{CONCLUSIONS}

The initiation and expansion of migration between Senegal and Europe stem from the simultaneous presence of several key factors at origin and destination, including processes of economic restructuring and the mutually reinforcing process of social capital formation and changing labor market conditions. These factors are historically contingent, but they may have a wider relevance in the explanation of migration from developing countries to developed countries.

\section{Introduction}

Although the literature on migration determinants in sub-Saharan Africa is extensive, most focuses on internal migration (Lucas 2006). Compared to the theoretical and empirical literature of international migration elsewhere, relatively little is known about international African migration, especially that outside the continent (Adepoju 2004; Lucas 2006; Grillo and Mazzucato 2008; Hatton and Williamson 2003). Most existing studies have adopted a qualitative approach, and the few quantitative studies are based either on aggregate data or cross-sectional micro-data (e.g., Hatton and Williamson 2003; Schoorl et al. 2000; van Dalen, Groenewold, and Schoorl 2005). As a result, there is a dearth of knowledge and quantitative empirical evidence about what drives migration from Sub-Saharan Africa, and whether this is similar to migration from other geographical regions.

Acknowledging the need for appropriate data to remedy this state of affairs, the Migrations between Africa and Europe (MAFE) project collected rich retrospective biographical data in several locations in Africa and Europe (Beauchemin 2012) ${ }^{3}$. Here we use MAFE data to examine the drivers of Senegalese migration to Europe between 1976 and 2008. This migration system is an example of migration from Sub-Saharan Africa to developed societies. Although comparatively modest in absolute numbers, this migration stream has developed quickly since the 1980s.

In this study we pay particular attention to the links between the micro-level factors that influence migration decisions and political, social, and economic processes in both Senegal and Europe. Very few empirical studies have examined how migration relates to historical social and economic transformations (Sassen 1988; Portes 1997; Castles and Miller 2009). Our perspective highlights the importance of institutions in

\footnotetext{
${ }^{3}$ MAFE investigates migration between Senegal and France, Italy, and Spain; migration between Ghana and the United Kingdom and the Netherlands; and migration between the Democratic Republic of Congo and Belgium and the United Kingdom.
} 
regulating migration behavior and shaping migration dynamics ${ }^{4}$. Particularly useful for our purposes are several insights from institutional approaches in economics and development research that analyze how social institutions regulate migration behavior (Stark 1991; de Haan 1999; Ellis 2000). The specific characteristics of the origin and destination labor markets are central to understanding migration (Piore 1979; Portes and Bach 1985; Reyneri 2003; Villarreal and Blanchard 2013). Social groups and relationships, including migration networks and families, greatly influence migration (Massey 1990; Stark 1991). Although different, the perspectives above share several conceptual parallels. They place individual behavior in a wider societal context, analyzing how social institutions function and their role in migration. By highlighting the role of families and social networks they take into account (household) decisionmaking. We argue that integrating these perspectives can enhance the understanding of migration processes through a more complete consideration of how origin and destination factors interact.

Our analyses focus on the following hypotheses:

1) Economic Insecurity Hypothesis: The long period of economic recession experienced in Senegal and the associated reshaping of social and economic relationships involved a general deterioration of living conditions and heightened economic insecurity, which created the conditions for increasing out-migration propensities.

2) Labor Demand Hypothesis: Labor market restructuring in Europe provided job opportunities in particular niches and locations.

3) Social Capital Hypothesis: For Senegalese migrants, social networks link the above processes by channeling job access in Europe.

4) Interaction between Labor Demand and Social Capital Hypothesis: The conjunction of periods of strong labor demand and the availability of personal networks in Europe creates a boosting effect on the migration probabilities of the Senegalese to Europe.

These hypotheses specify under what conditions particular mechanisms, proposed in previous literature, are activated, leading to the development of the migration system between Senegal and Europe. We emphasize that the simultaneous presence of the factors involved in the hypotheses is needed for the emergence and continuation of a migration system. Although our propositions apply to a particular migration system, we

\footnotetext{
${ }^{4}$ Alejandro Portes (2010, p. 1543) defines institutions as "the symbolic blueprint for organizations; they are the set of rules, written or informal, governing relationships among role occupants in social organizations like the family, schools and other major areas of social life: polity, economy, religion, communications and information, leisure."
} 
believe they have a general applicability in explaining migration from developing to advanced countries.

We adopt a life course framework, which is useful for analyzing how local institutions mediate the influence of global forces on individual life courses (Mayer 2001). The complexity of life course analysis can be handled using event history techniques, which are useful tools for exploring how well propositions fit patterns of observed behavior (Blossfeld, Golsch, and Rohwer 2007).

The paper is structured as follows. First, we outline migration trends from Senegal to Europe. Second, we examine the theoretical basis and the existing evidence for each of the four hypotheses proposed. This is followed by a presentation of the data and the methods. In spite of data limitations, the results section provides empirical evidence remarkably consistent with our hypotheses. We conclude with a discussion of how the simultaneous presence of several factors underpins the development of a new migration stream.

\section{The surge of Senegalese migration to Europe}

During the last three decades, international migration from Senegal has reached a much higher level than is usually associated with a country of very low development levels (Massey et al. 1998; Martin and Widgren 1996; Hatton and Williamson 2003) ${ }^{5}$. According to the 2002 Senegal Census, 479,515 Senegalese resided in another country, while the Ministry of Senegalese Living Abroad estimated approximately 648,600 individuals to be living abroad in 2003-2004, from a total population of about 10 million (Agence Nationale de la Statistique et de la Démographie 2006; Development Research Centre 2007). Substantial and increasing shares of these migrants have settled in Europe $(190,000)$ and, to a lesser extent, in North America $(43,200)$. The main European destinations are, by far, France, Italy, and Spain. At the same time, flows to other African countries have stagnated ${ }^{6}$.

In many regions of the country, migration has become a social institution in itself, with its own logic and social norms that influence who is sent abroad, their remittance behavior, and their transnational practices (Guilmoto 1998; Massey 1990). Families and individuals rely on migration as a legitimized strategy to increase resources and redistribute labor. This institutional patterning of migration, which has long governed internal as well as intra-Africa mobility, is now also well established for migration to Europe. A large and increasing proportion of the population in Senegal is linked by personal networks to Europe (Agence Nationale de la Statistique et de la Démographie

\footnotetext{
${ }^{5}$ Senegal ranked 166 out of 182 countries in the Human Development Index in 2006 (UNDP 2009).

${ }^{6}$ Senegal had a positive net migration until the end of the 1970s (ANSD 1995).
} 
2004). Furthermore, in the last few decades, migration has become increasingly vital for the functioning of the Senegalese economy. Remittances are believed to represent about $12 \%$ of the gross domestic product (World Bank 2008; Banque Centrale des Etats de l'Afrique de l'Ouest 2008).

Senegalese migration to Europe has its roots in colonialism. The first migrations resulted from recruitment efforts by the French army and administration during colonial times. Starting in the 1950s, rapidly expanding French industry actively recruited significant numbers of male workers from Senegal. By the mid 1970s, when the French government started to restrict labor immigration, a significant Senegalese community was established in France. As in many other European countries during this period, family reunification then became the main conduit of legal immigration (Pison et al. 1997; Robin, Lalou, and Ndiaye 1999). Decreasing opportunities and increasing restrictions on migration to France during the 1980s fueled new migration flows to Italy, and by the end of the decade the flows spread to Spain. In the last thirty years, Senegalese migration to European countries has steadily grown. Results from the MAFE survey estimate that the lifetime probability of adult migration from Senegal to Europe sharply increased from $6 \%$ in $1975-1989$, to $9 \%$ in the 1990 s, and to $12 \%$ in 2000-2007 (Sakho 2013). Meanwhile, migration to African destinations decreased from about $8 \%$ in the first period to about $6 \%$ in the following periods (Sakho 2013). Migration to African countries, which often has a strong short-term and seasonal component, has been negatively affected by political and economic developments in destination countries. A focus on the precise circumstances and transformations occurring in the last thirty years at either end of the migratory flow is necessary to understand migration dynamics.

\section{Linking theories with context}

\subsection{Migration as a response to increased economic insecurity}

Social and economic structural transformations create powerful motivations for international migration and lead people to actively search for new ways to advance and achieve economic security (Portes 1997; Castles and Miller 2009). In the case of Senegal, the adoption of a new model of development in the mid-1980s and the shifting of migration patterns clearly coincided in time.

Post-independence economic policy was characterized by an import-substitution strategy and by intensive government regulation (Boone 1991). Economic development was based on the production of groundnut for export, while French-capital-funded enterprises and state enterprises continued to dominate the formal-sector industry, 
commerce, and banking. This model of economic development came to an end in the late 1970s when the country suffered a deep economic crisis, aggravated by plummeting world groundnut prices and severe droughts between 1978 and 1981. Real gross domestic product per capita fell by $15 \%$ between 1975 and 1995 and did not recover until 2005 (World Bank 2012; Figure 1). As a response to the crisis, the government cooperated with the International Monetary Fund and the World Bank to implement several structural adjustment plans, culminating in the drastic devaluation of the currency in 1994 (Duruflé 1988; Collier and Gunnig 1999; Azam 2004; Thioub , Diop, and Boone 1998).

The period since the early 1980s has been characterized by a drastic liberalization of the economy, including the privatization and downsizing of state enterprises, market deregulation, and trade barrier reduction. These policies did not remedy recurrent agricultural crises, which, amplified by ecological conditions and policy decisions, led to a severe deterioration of living conditions in rural areas. The government progressively decreased its support of farmers' incomes by deregulating the markets, privatizing agricultural organizations, and limiting government policies such as buying groundnut at a guaranteed price. Rural income levels fell drastically, poverty became widespread, and food insecurity became a constant threat (Bruzzone et al. 2006). Responding to deteriorating economic and ecological conditions, the population adopted several livelihood strategies: the diversification of agricultural production (mostly to subsistence crops); the diversification of economic activity during the dry season to include activities such as small trade and crafts; seasonal or permanent migration to the cities; and international migration.

In urban areas the decline of the state sector and industry motivated significant cuts in real wage rates and an expansion of the informal sector (Antoine et al. 1995; Azam 2004). Formal sector job loss following the 1986 New Industrial Policy was massive, and industrial production declined substantially. In particular, the capital city Dakar experienced a profound transformations of its local labor market, with a severe reduction in highly qualified jobs and substantial job creation in the informal sector from the mid-nineties (Bocquier 1996; Thioub, Diop, and Boone 1998) ${ }^{7}$.

\footnotetext{
${ }^{7}$ Different sources estimate the informal sector as between $80 \%$ and $90 \%$ of Senegal's total active population (International Labor Office 2002; Banque Mondiale 2007).
} 
Figure 1: Trends in Gross Domestic Product per capita in Senegal (left axis) and total number of individuals from all nationalities employed in France, Italy, and Spain (right axis)

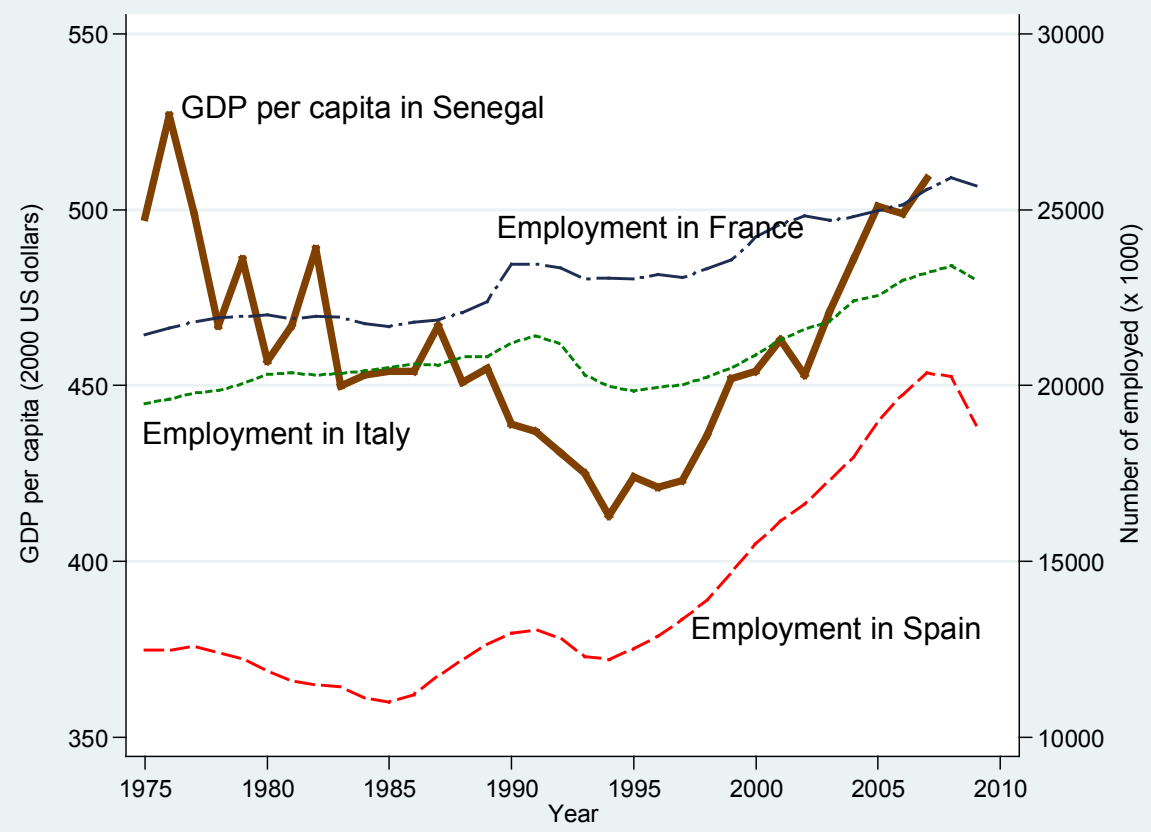

Source: The World Bank 2012 for GDP; OECD 2010 for employment. Note that the vertical axis ranges are displayed from value 350 (left axis) and 10,000 (right axis).

Overall, liberalization policies did not produce the expected economic growth and stabilization, although some irregular improvements took place from the late 1990s (Figure 1). Well-functioning markets - the goal of these policies - are largely absent. Furthermore, economic development has been hampered by poor public services and infrastructure (Collier and Gunning 1999). Foreign investment has been minimal, discouraged by an unfriendly and risky business environment (Banque Mondiale 2007). In an economy where most of the population works in family agriculture that is largely based on kin relationships, and where most of the economy remains informal, the strength of market relationships is limited.

As in many Sub-Saharan Africa countries where state power and infrastructure are weak, economic and social relationships remain largely dependent on kinship and 
community bonds and values. Strong ties of reciprocity and patronage link agents of the state with local businesses and religious or communal organizations (Fatton 1986; Thioub, Diop, and Boone 1998; Galvan 2001). Liberalization further decreased state power and, as the new development model created new constraints and opportunities, individuals mobilized these community-based forms of social capital. The long period of economic recession resulted in a general decrease in real income, increased inequality, and chronic economic insecurity, with a larger proportion of people affected by poverty (Duruflé 1988; Weissman 1990). In such a context, migration can be interpreted as a strategy of individuals and households to cope with economic stress, as suggested by the New Economics of Labor Migration and the 'sustainable livelihoods' literature (Stark 1991; Ellis 2000; Scoones 1998; Barrett, Reardon, and Webb 2001; Kothari 2002) ${ }^{8}$. It can thus be expected that negative economic growth increases migration propensities. Individual-level indicators of insecurity, informality, and unemployment are likely to lead to the same result.

The key role of families in Sub-Saharan African migration has been widely recognized (Findley 1997; de Haan 1999). Formal insurance and financial markets are out of reach for most of the population: in such circumstances, family links provide security by pooling risks (and rewards) and providing the resources to migrate. Migration by family members allows the household to diversify its income sources; they will be obtained in markets whose risks and rewards are lowly correlated. A 'migration contract' regulates the reciprocal obligations of different family members (Stark 1991). Sending a family member to Europe may provide the means to afford consumer goods and invest in a business or, more often, a dwelling, thus enhancing the whole family's social status and well-being. The importance of the family dimension in Senegalese migration has been demonstrated in such crucial issues as financing migration, transnational family practices, and remittance and investment behaviors (Mezger and Beauchemin 2010; Baizan, Beauchemin, and González-Ferrer 2014). Other individuals may be involved in a 'migration contract' including more distant kin, members of the same ethnic or religious group, or network members met during the migration process, even if their reciprocal obligations are unequal (Guilmoto 1998; Krissman 2005). Mutual dependence and group affiliation do not seem to exclude the growing importance of individual motivation and decision-making, especially for the highly educated (Lalou and Ndione 2005).

Increased economic insecurity and lower incomes push individuals and families to look for alternative and diverse sources of income. Migration can thus be a strategy to protect income stability through both the diversification of income sources and the accumulation of human and/or financial capital. Income obtained by migrants plays a

\footnotetext{
${ }^{8}$ Migration hikes in the wake of economic reform have been observed in several countries (Martin 1993), although in Senegal, as in several other African countries, the 'crisis' has lasted several decades.
} 
key role in improving living standards, including food security, in different parts of Africa (Findley and Sow 1998; Lindstrom, Hadley, and Belachew 2012). Furthermore, the spread of the informal economy may encourage higher rates of migration (Krokfors 1995; Villarreal and Blanchard 2013).

Increasing socio-economic inequality may be an additional incentive for migration. This is precisely the idea behind the hypothesis of relative deprivation developed by Stark (1991), but also in other studies that conceive migration as a strategy not only to increase income but, more widely, as a way to avoid downward social mobility, and more generally to enhance social status (Piore 1979; Reyneri 2003). The set of processes briefly referred to in the preceding paragraphs can be summarized in our Economic Insecurity Hypothesis: The long period of economic recession experienced in Senegal and the associated reshaping of social and economic relationships involved a general deterioration of living conditions and heightened economic insecurity, which created the conditions for increasing out-migration propensities.

\subsection{New employment opportunities in Europe}

In the mid-1980s, migration to other African destinations became less attractive, since the economic and political conditions in most neighboring countries were as poor, or even poorer, than in Senegal. Initial Senegalese migration to Europe was directed towards France, but soon Italy and later Spain became major destinations. Overall employment growth in these countries has been substantial since 1985, with the exception of the crisis periods in the early 1990s and after 2008 (OECD 2010; Figure 1). The economic restructuring and labor market deregulation that started in the 1980s in Southern European economies, together with employers' practices, resulted in the creation of many temporary and low paid jobs (Polavieja 2003; Reyneri and Fullin 2011). In a context already dominated by small-sized firms, improvements in competitiveness were largely achieved through increased labor flexibility, subcontracting, or informal practices, with an increasing dualization of the labor market and a sub-protective welfare regime (Gallie and Paugam 2000). Many of the most precarious and unskilled jobs created during this period became less and less attractive to natives, who were progressively better educated and could afford to wait for better job offers. Alongside a greatly expanded informal economy, these factors created the conditions for a strong demand for migrant labor and favored especially the hiring of irregular migrants (Reyneri 2003; Reyneri and Fullin 2011). Our second hypothesis, based on the above arguments, is: Labor market restructuring in Europe provided job opportunities in particular job niches and locations (Labor Demand Hypothesis). 
In such a context it is hardly surprising that Senegalese occupy jobs located nearly exclusively in the secondary labor market, with very low socio-economic status and poor working conditions (Castagnone et al. 2013). Senegalese male migrants succeeded in gaining footholds as factory workers or low-level service workers in the industrial districts of Northern Italy and Eastern Spain. Intensive agriculture and peddling are also relevant niches (Bruzzone et al. 2006; Castagnone et al. 2013). It should be emphasized that family and personal networks, i.e., social capital, are by far the primary means to obtain jobs in Southern European labor markets, especially in low-skilled occupations (Barbieri 1997). This explains the concentration of migrants in specific occupations and places, since social capital greatly improves job access and reduces the probability of unemployment. At the same time, this functioning of the labor market then limits both a migrant's chances of getting jobs outside the migrant network and socio-economic mobility (Portes and Rumbaut 2001; Reyneri and Fullin 2011).

In France the development of the informal economy and the process of labor market deregulation have been slower and more limited (Gallie and Paugam 2000), which helps explain the more heterogeneous socioeconomic profile of the Senegalese community there, with larger roles for education and family reunification as motives for migration but also a decreasing importance of France as the main destination for Senegalese in Europe, at least in relative terms (Castagnone et al. 2013).

Greater employment opportunities in European labor markets coexisted with increasingly restrictive admission policies. However, policy restrictions differed in their timing and intensity across countries and type of migration (see Mezger and GonzálezFerrer 2013 for a cross-country analysis). France, as an older country of immigration, has had well-developed state structures for both integration and border control since almost the beginning of the Senegalese flows; this was not, however, the case in Italy or Spain (Ambrosini 2001). For example, the late introduction of an entry visa requirement

in Italy (1990) along with a large demand for cheap unskilled labor favored large inflows and irregular work for many migrants. Increasing entry restrictions have contributed to making migration more risky and costly but have not necessarily reduced entry. Periodical regularizations in Italy and Spain have contributed to consolidate Senegalese communities and provide access to regular and better jobs and legal options for family reunification.

\subsection{Personal resources and the viability of migration as a strategy}

To be used as a strategy to fight poverty, insecurity, or downward social mobility, migration is largely dependent on the resources available to the individual and their 
household. These resources are relevant not only to pay for the actual trip ${ }^{9}$, but are important in a wider sense. Economic, social, and human capital resources strongly influence the ability to migrate and explain migration's limited prevalence and its strong selectivity. This links the capability to migrate to an individual's social position, including such attributes as age, gender, education, family status, occupational status, and access to networks abroad. Social institutions and organizations facilitate/impede access to these resources and to migration in general (Findley 1997; Scoones 1998). In particular, the household economy context mediates the role of individual attributes.

Migration behavior is very much related to the life stage. During young adulthood, individuals seek adult roles and status, for which migration is often an instrumental behavior (Mulder 1993). Most prominent in this respect are the work career and family formation. The economic and normative context of extended families, characteristic of Senegal's major ethnic groups, involves strong age and gender hierarchies that impinge upon individual decision-making, although this sometimes leads to youth migrating to escape family control (Findley 1997). Young people are favored for migration for several reasons. First, job opportunities in destination countries strongly favor the young (Heath and Cheung 2007). Second, young adults generally have lower opportunity costs of leaving jobs at origin. Third, young people have a longer time span to reap the benefits of migration. However, a substantial part of Senegalese migration to Europe appears to reflect a 'target earnings' strategy, with stays lasting five years or less (González-Ferrer et al. 2014).

Gender is another decisive factor, and gendered social and family hierarchies severely restrict Senegalese women's capability to migrate abroad independently. Family values and norms stress that household and care work are the main obligations of women (David 1995). For instance, married women are obliged to take care of their mother-in-law, restricting mobility (Diop 1985; Poiret 1996). In this context, household allocation of labor discourages migration for women, as the cost of staying abroad is higher than remaining at home, and as it lowers the amount of remittances received by the household. Although Southern European labor markets offer a wealth of 'femalespecific' (often informal) jobs in the secondary labor market in agriculture, domestic service, dependent care, and other services, Senegalese women seldom take these opportunities, even when they already reside in Europe (Castagnone 2013). In sum, we expect labor migrants to be predominantly male, and female migration to be more commonly related to either couple formation or family reunification.

\footnotetext{
${ }^{9}$ The United Nations Office on Drugs and Crime estimated the cost of irregular travel between Senegal and the Canary Islands to be between US\$480-1,930 in 2006 (UNODC 2006). Funding is often covered with the help of family members or by social networks abroad, which are clearly related to the social status of the would-be migrant and their family.
} 
Migration propensities are expected to differ by occupational status, since employment can fund migration but also entails different opportunity costs. Individuals with low socio-economic status often lack the resources to migrate, while high-socialclass individuals have both less economic incentive to migrate and higher opportunity costs of quitting good jobs. Accordingly, the relationship between migration and socioeconomic status is expected to follow an inverted U-shape. Migration also often implies downward social mobility, at least initially, making it less attractive for individuals holding high-status jobs (Obucina 2013). Unemployment is an indicator of economic insecurity, leading to higher migration propensities (relative to the employed). Positive selection with regard to human capital characterizes migration from developing to developed countries (Hatton and Williamson 2003). Although often attributed to the greater financial resources of individuals with higher education and skills, their advantage in European labor market job searches should also be emphasized. A strong positive selection according to education can be expected in our empirical analyses.

\subsection{The interaction between social capital and labor demand}

The role of migrant networks in facilitating the migration process has been extensively highlighted in the literature, although less attention has been paid to the conditions under which this form of location-specific social capital leads to migration (Massey et al. 1998; Garip 2008). Migrant networks can facilitate potential migrants' access to migration-related resources, including information, financing, housing, marriage partners, and, crucially, access to job opportunities. As mentioned previously, jobs at destination are generally not filled through a bureaucratic open-market job search that sorts prospective workers for available slots, but rather through the personal networks of current employees. The mediating effect of the migrant network is expressed by providing job opening information to potential migrants and providing referrals to employers. Employers also favor this type of recruitment because it helps solve information asymmetry problems (Munshi 2003; Granovetter 2005). Additionally, Rosenfeld and Tienda (1999) write "network hiring lowers employer's cost of recruiting and provides employers with some insurance that the new employees will not shirk their duties, because a current worker has vouched for them." When new personnel are needed, networks are mobilized, and this can explain the expansion of migrant streams according to personal networks. The availability of social capital abroad is likely to be especially crucial for migration from a poor country to a developed country. Thus, our third hypothesis is: Social networks link livelihood strategies by individuals and households in Senegal with labor demand in Europe, by channeling access to jobs for Senegalese migrants (Social Capital Hypothesis). 
Potential migrants without networks cannot migrate to take advantage of specific increases in labor demand because they lack access to the new jobs ${ }^{10}$; but the availability of social capital abroad may not be enough to trigger migration. Therefore, we hypothesize that a simultaneous presence of labor demand at destination and social migrant networks is needed to trigger labor migration: The conjunction of periods of strong labor demand and the availability of personal networks in Europe creates a boosting effect on the probability of migration from Senegal to Europe (Interaction Between Labor Demand and Social Capital Hypothesis).

Networks tend to develop among individuals belonging to the same groups, particularly those based on kinship, religious affiliation, social class, and ethnic group. In heavily segmented societies, as is the case of Senegal, non-group members may see themselves excluded from migration, leading to sharp contrasts in migration propensities between individuals with and without networks abroad. Furthermore, not all network members are equally useful for finding jobs in Europe and for migration. As discussed previously, destination labor markets provide different opportunities according to age, sex, and especially education, likely resulting in differential migration opportunities among network members. For the Senegalese, both strongly tied and weakly tied personal networks are important (Liu 2013), and network composition is gendered (Toma and Vause 2011).

Networks have a random component, since they depend heavily on initial conditions and the path-dependent way that they develop. For instance, the ability and luck of pioneer migrants to find jobs in particular occupational niches and geographical locations in Italy and Spain have distinctly shaped the characteristics and size of the respective Senegalese communities ${ }^{11}$. The expansion of networks in these countries has been related and limited to the expansion of job opportunities in these particular occupational niches and locations. Migration opportunities in Senegal have expanded among individuals connected to former migrants in a path-dependent way.

Finally, network development continuously alters the conditions under which subsequent migration takes place (Massey 1990; de Haas 2010). The selectivity and path-dependence dynamics of networks means that “... when mobility results from network connections, it changes network structure that then feeds back into future mobility patterns" (Granovetter 2005, p. 37) ${ }^{12}$. Feedback effects in the destination society include the creation of migrant-origin-specific job niches, new migrant associations, and the increased availability of smugglers (Krissman 2005). In the origin

${ }^{10}$ By the same token, labor demand may not lead to immigration (by the Senegalese) if networks are unavailable.

${ }^{11}$ Of course, these factors have also been important in France. However, the initiation of migrant networks there is more complex and less clearly identifiable in time, since it has a longer history in which colonialism and post-colonial ties, as well as labor force recruitment, have played an important role.

${ }^{12}$ Here, Granovetter's words refer to job mobility, but we apply them to geographic mobility. 
society, development of the migration system results in the increasing diffusion and strength of networks in the population, and also greater income inequality between migrant and non-migrant households and the economic dependence of households on remittances. Once established, a 'migration culture' legitimizes and normalizes the process. The development of these processes over the last thirty years has produced a multiplier effect on migration at the aggregate level, which likely drives the expansion of the migration system between Senegal and Europe.

\section{Data and variables}

We base the empirical analyses on the survey 'Migrations Between Africa and Europe' (MAFE-Senegal Biographical Survey) ${ }^{13}$. This transnational dataset results from the use of identical questionnaires and similar survey methods in Europe and in Senegal: 603 Senegalese migrants were surveyed in Europe, irrespective of the Senegalese region of residence prior to migration (about 200 each in France, Italy, and Spain ${ }^{14}$ ) and 1,067 persons were interviewed in the region of Dakar (including 197 returnees and 101 migrants' partners at the time of the survey in 2008). The resulting sample size $(1,670)$ is sufficient to ensure that event history analyses conducted on this data provide statistically significant results (see results section below), taking into account the life course character of the data and that migrants are oversampled with respect to origin population. In all countries the survey eligibility criteria was that individuals were between 25 and 70 years of age (for sufficiently long life histories), had been born in Senegal (to exclude the second-generation in Europe), and had current or past Senegalese nationality (to exclude immigrants to Senegal). Additionally, for those living in Europe, their first international migration was at age 18 or older, in order to focus on adult migration. Therefore, the MAFE survey is a representative sample of the Senegalese birth-cohorts born between 1940 and 1982 and currently living either in the Dakar region or in France, Italy, or Spain (Beauchemin 2012).

\footnotetext{
${ }^{13}$ The Senegalese part of the Migration between Africa and Europe (MAFE) project is coordinated by INED (C. Beauchemin), in association with the Université Cheikh Anta Diop (P. Sakho). The project also involves the Universitat Pompeu Fabra (P. Baizan), the Consejo Superior de Investigaciones Científicas (A. GonzálezFerrer), and the Forum Internazionale ed Europeo di Ricerche sull'Immigrazione (E. Castagnone). The survey was conducted with the financial support of INED, the Agence Nationale de la Recherche, the Région Ile de France and the FSP program 'International Migrations, territorial reorganizations and development of the countries of the South'. The MAFE-Senegal project has now been enlarged to Ghanaian and Congolese migrations, thanks to a funding from the EU Seventh Framework Programme. For more information (including the questionnaires) see: http://www.mafeproject.com/.

${ }^{14}$ For simplicity's sake, we will refer to 'Europe' instead of mentioning the three different destination countries in the rest of the article.
} 
The MAFE Senegal survey's geographical strategy for surveying Senegalese migrants is astute. On one hand, France, Spain, and Italy accounted for about $45 \%$ of the Senegalese diaspora, as reported in the 2002 Senegal Census (Agence Nationale de la Statistique et de la Démographie 2006). On the other hand, the Dakar region is home to about a quarter of the national population and the origin of $31 \%$ of the international migrants reported by Senegalese households in the 2001-2002 ESAM-II survey (ANSD 2004 and 2006). However, the inconsistency of including migrants from all regions of Senegal in the European samples while only surveying the region of Dakar should be noted. We address this issue by conducting separate analyses for the whole of Senegal and for migrants from the Dakar region. As is shown below, these analyses provide similar results, suggesting that the variables included account for the compositional differences between the Dakar region and the rest of Senegal (see sections on methods and results). In spite of its drawbacks, the MAFE survey is a very significant improvement, in both methodological and substantive terms, on existing data sources for international migration, particularly regarding African migration to Europe. It provides a unique source of rich life course data that avoids the methodological problems of data collected in just one country (Beauchemin 2014).

Varied sampling methods were used to select the individuals. In Senegal a stratified probabilistic sample was drawn, based on census data. The municipal register in Spain (Padrón) offered a national sampling frame from which documented and undocumented migrants could be randomly sampled. Respondents in France and Italy were sampled through various non-probabilistic methods (e.g., snowballing, intercept points, contacts obtained from migrant associations) in order to fill pre-established quotas according to sex and age (Beauchemin and González-Ferrer 2011; Beauchemin 2012).

The data are time varying by nature, since they result from individual life histories collected in biographical questionnaires. The questionnaire was designed to collect retrospective information on a yearly basis from birth until the time of survey (2008) for each sampled individual, whatever his/her country of residence at the time of the survey. Information was collected on individuals' migration, education, and work history, as well as their family history (children, partnerships) and social network. This type of data collection is susceptible to recall errors and omissions. Fortunately, omissions should be minimal for salient events such as international migration or important family events (like births or marriage); but errors are likely to be more frequent for some categories of network member or in the case of complex job histories (Auriat 1996). Crucial for event history analysis, the sequence of events is generally accurate in retrospective surveys, leading to reliable estimates of the effects of the explanatory variables (Courgeau 1992). The MAFE surveys followed a number of procedures to minimize recall errors and to improve data quality, such as face-to-face 
interviews, the use of an event-history calendar in interviews ${ }^{15}$, consistency checks at different stages of data collection, and the possibility to re-contact the interviewees to correct inconsistencies or missing data. ${ }^{16}$

Our dependent variable, migration out of Senegal, is defined as a stay of at least 12 months outside Senegal. In the analyses we include only direct first migrations from Senegal to France, Italy, or Spain, resulting in 560 first migrations. Moves from Senegal to other destinations were censored at the year of migration. The decision to analyze first migration moves only is motivated by the fact that only 66 subsequent moves were recorded in the survey, preventing statistically reliable separate analyses ${ }^{17}$. Moreover, focusing on first migrations should provide higher clarity regarding the analysis of migration determinants, since first and subsequent migrations are likely to involve different costs and circumstances (e.g., knowledge of the destination labor market, availability of a migration permit, resources earned in previous migrations). In order to gain a more precise focus on labor-related migration, we distinguish labor migration from other migration types in some models ${ }^{18}$. The distinction is based on labor force status at destination during the first year after migration. If the individual is employed or unemployed, the move is classified as 'labor migration' $(60 \%$ of total moves); and if $\mathrm{s} / \mathrm{he}$ is inactive, notably including housewives and students, the move is classified as 'other'. Here, we isolate labor migration from other motivations to better assess the role of the independent variables included in the models. However, these migration types are generally not independent from each other. Family reunification and marriage migration are often related to a previous labor migration (Baizan, Beauchemin, and González-Ferrer 2014). Students may eventually enter the destination labor market (Castagnone et al. 2013). The interrelation of migration motives also explains why we prefer to use an 'objective' distinction rather than use the stated motives of migration given by migrants in the questionnaire. Additionally, subjective answers are often ambiguous (for instance, they may include a first motive related to economic reasons and a second motive related to family or 'adventure').

In Table 1 we present some descriptive statistics of the variables used in the models: mean values (for continuous variables such as age) or the frequency distribution (for categorical variables such as activity status), and their standard errors.

\footnotetext{
${ }^{15}$ This calendar presents life trajectories in a parallel way, with cells for each calendar year, allowing easy detection of inconsistencies or omissions (e.g., no empty durations are allowed for places of residence from birth to interview date). Interviewees could see how their answers were recorded and correct them if necessary.

${ }^{16} \mathrm{An}$ assessment of the survey data quality is outside the scope of this paper. Additional information can be found in Beauchemin (2012) or on the website of the MAFE project http://www.mafeproject.com/

${ }^{17}$ Analyses of repeated moves, including an individual-level heterogeneity term in the model, yield very similar results to those presented here.

${ }^{18}$ Note that for the period and birth cohorts involved in this study, all migration moves can be considered as 'voluntary'; i.e., no refugee or asylum seeker migration was reported.
} 
On the one hand, we show the values of the variables either measured at migration time for individuals that have migrated to France, Italy, or Spain, or measured at censoring time (i.e., at survey time or at migration to other destination) for other individuals. On the other hand, we present the means and the frequency distribution, computed out of the total number of person-years in the sample, in order to account for time-varying variables. Independent variables include age, gender, number of children, and partnership status (individuals married or in a consensual union versus not being in a partnership). A time-varying indicator of the educational level has been constructed, based on answers regarding the main occupation of individuals and their educational attainment. The relatively high proportion of individuals with very low educational levels $(29 \%$ of individuals in our sample had no schooling at survey time; $42 \%$ had some primary education only) is consistent with existing census data for the birth cohorts involved, and with the slow expansion of education in Senegal (ANSD 2006). The data distinguish periods when the individual was employed, unemployed, studying, or in other type of economic inactivity, based on the question "What was your primary occupation during this period?" Self-reported activity measured in this way may not coincide with standard activity definitions. In particular, unemployment and inactivity are likely to be underestimated in a context with a widespread informal economy and underemployment. The questionnaire provides information on the individual's job during each activity period (each change in occupation or occupational category implies a separate activity period), based on the questions "What was your exact occupation during this period? What were your tasks?" Information on professional occupations was coded using the ISCO-08 International Labor Office classification, and was subsequently collapsed into a simplified version of Erikson and Goldthorpe's class categories (1992). The 'family help' variable includes periods when the individual is helping their own family's business or farm, or when the employer is a private household (domestic work). The 'work experience' indicator was constructed using the logarithm of the number of years that an individual has held a job as main occupation $(\log +1$; individuals who never worked have 0$)$. An additional indicator of an individual's resources is whether s/he owns property in Senegal, including land, dwellings, and business. 
Baizán \& González-Ferrer: What drives Senegalese migration to Europe?

Table 1: Sample's descriptive statistics: proportion or mean values of the variables included in the models for first migration from Senegal to France, Italy or Spain (F, I, S)

\begin{tabular}{|c|c|c|c|c|}
\hline & \multicolumn{2}{|c|}{ Person-years in the sample } & \multicolumn{2}{|c|}{$\begin{array}{l}\text { Values at migration (for migrants } \\
\text { to } \mathrm{F}, \mathrm{I}, \mathrm{S} \text { ) or at censoring (for } \\
\text { others) }\end{array}$} \\
\hline & $\begin{array}{l}\text { Proportion or } \\
\text { mean }\end{array}$ & Standard error & $\begin{array}{l}\text { Proportion or } \\
\text { mean }\end{array}$ & Standard error \\
\hline Age (mean) & 32.104 & 0.128 & 36.466 & 0.558 \\
\hline Woman & 0.561 & 0.005 & 0.515 & 0.021 \\
\hline \multicolumn{5}{|l|}{ Level of education } \\
\hline No schooling & 0.361 & 0.005 & 0.293 & 0.019 \\
\hline Primary or less & 0.431 & 0.005 & 0.429 & 0.021 \\
\hline Secondary & 0.168 & 0.004 & 0.210 & 0.016 \\
\hline University & 0.040 & 0.002 & 0.068 & 0.010 \\
\hline \multicolumn{5}{|l|}{ Activity } \\
\hline Student & 0.099 & 0.003 & 0.062 & 0.009 \\
\hline Employed & 0.563 & 0.005 & 0.614 & 0.020 \\
\hline Unemployed & 0.030 & 0.001 & 0.054 & 0.010 \\
\hline Other inactive & 0.308 & 0.005 & 0.269 & 0.019 \\
\hline \multicolumn{5}{|l|}{ Socio-economic status (for employed) } \\
\hline Higher service & 0.195 & 0.005 & 0.193 & 0.019 \\
\hline Routine non-manual & 0.223 & 0.005 & 0.262 & 0.023 \\
\hline Skilled manual & 0.267 & 0.006 & 0.267 & 0.024 \\
\hline Unskilled manual & 0.251 & 0.006 & 0.224 & 0.023 \\
\hline Agriculture & 0.063 & 0.003 & 0.054 & 0.011 \\
\hline Family help (for employed) & 0.189 & 0.006 & 0.169 & 0.021 \\
\hline Work experience (mean years) & 9.603 & 0.116 & 12.571 & 0.525 \\
\hline Owns property in Senegal & 0.131 & 0.003 & 0.203 & 0.017 \\
\hline \multicolumn{5}{|l|}{ Partnership status } \\
\hline No partner & 0.423 & 0.005 & 0.383 & 0.020 \\
\hline In partnership & 0.577 & 0.005 & 0.617 & 0.020 \\
\hline Number of children (mean) & 2.501 & 0.037 & 2.525 & 0.134 \\
\hline Individual has network in France, Italy, or Spain & 0.275 & 0.005 & 0.506 & 0.021 \\
\hline$\%$ GDP per capita growth in Senegal (mean) & 0.519 & 0.029 & 1.572 & 0.040 \\
\hline $\begin{array}{l}\text { \% Employment growth in France, Italy, or Spain } \\
\text { (mean) }\end{array}$ & 1.090 & 0.014 & 1.686 & 0.028 \\
\hline Person years (unweighted) & 23900 & & - & \\
\hline No. individuals (unweighted) & 1551 & & 1551 & \\
\hline No. of migrations to $\mathrm{F}, \mathrm{I}$, or S (unweighted) & 560 & & 560 & \\
\hline
\end{tabular}

Source: MAFE-Senegal 2008. Weighted data.

The measurement of social networks is very detailed in MAFE data. Respondents were first asked to name all close family members (parents, siblings, partners, and children) who had lived at least one year abroad, and construct a year-by-year itinerary of the countries where they had lived. Subsequently, they were asked to provide the itineraries of other relatives, friends, and acquaintances who they could count on (or could have counted on) to receive or help them to migrate out of Senegal, who had also lived at least one year abroad. In the analyses presented here, we restrict migrant 
network indicators to years lived in the three European countries studied. The network variable indicates whether the respondent has network members living in Europe, excluding their spouse.

In order to take into account the numerous family reunifications and marriagerelated migration, we use the indicator 'partner's location', with three categories: not in union, partner lives in Europe (France, Italy, or Spain), and partner is not in Europe (in nearly all cases of this final category, the partner lives in Senegal).

With the exception of age and 'partner's location', all individual-level timevarying covariates are lagged one year with respect to migration decisions, to capture the ordering of life course transitions. Partner's location is not lagged in order to capture the simultaneity between union formation and migration.

We include two contextual variables in our analyses, based on the data presented in Figure 1. The first is the annual change, in percentage terms, of Gross Domestic Product per capita, which indicates the economic conditions in Senegal. This data, expressed in constant, year 2000 US dollars, is obtained from the World Bank database (2012). The second variable, intended to proxy labor demand, is the annual employment growth rate in France, Italy, and Spain, based on the Labor Force Surveys (OECD $2010)^{19}$. This indicator includes individuals of all nationalities living in these countries (i.e., not only Senegalese). These contextual variables were available starting from 1976, resulting in the subtraction of 47 individuals from the original sample. Additionally, 72 observations were dropped from the original 1,670 valid interviews because they migrated at age 18 to other destinations outside the three countries studied or because they had already made a first migration before age 18 . As a result of these reductions in the initial sample there are 1,551 individuals in our analytical sample and 560 first migrations made directly from Senegal to France, Italy, or Spain $(1,306$ individuals and 365 first migrations in the analyses including migrants from the Dakar region only).

\section{Methods}

Event history techniques are used to model the determinants of individuals' first migration decisions. In the discrete-time version of these techniques, the hazard function is modeled as the probability of the event taking place in a given interval, conditional on the fact that the event did not occur before for a given individual and on a set of covariates. A logistic specification is used, which can be viewed as a latent-

${ }^{19}$ Unfortunately, no reliable time varying indicator of income inequality covering the period analyzed is available. The World Bank provides Gini coefficients for 2011 (40) and 2005 (39) that suggest it is a very unequal society. The income share held by the lowest $20 \%$ of the distribution was $6 \%$ in 2011 . 
Baizán \& González-Ferrer: What drives Senegalese migration to Europe?

response model (Rabe-Hesketh and Skrondal 2012) ${ }^{20}$. Underlying the observed dichotomous behavior $y_{i t}$ (whether or not an individual migrates at a given age ${ }^{21}$ ), there is an unobserved or latent continuous response $y_{i t}{ }^{*}$, representing the propensity to migrate. If the latent response is greater than 0 then the observed response is 1 ; otherwise it is 0 . A linear regression model is specified for the latent response $y_{i t}{ }^{*}$

$$
\mathrm{y}_{\mathrm{it}}{ }^{*}=\beta_{0}+\beta^{\prime} \mathrm{x}_{\mathrm{it}}+\mathrm{u}_{\mathrm{it}}
$$

where $x_{i t}$ is a vector of covariates, including the baseline hazard function (individual's age), with $\beta$ denoting the value of the estimated coefficients of the model for each variable, and where the random term $u_{i t}$ is assumed to follow a logistic distribution ${ }^{22}$. A competing risk specification is used to model migration types. To facilitate interpretation we present the logistic regression results in odds ratios. In order to apply discrete-time event history models a person-year file is constructed, containing 23,900 observations $(19,477$ for the model for the Dakar region). Individuals enter the risk set when they reach age 18 and they leave it when they either migrate to Europe or reach year 2008 (survey time) ${ }^{23}$. If individuals migrate to other destinations they remain in the file until the year they migrate. It can be noted that the fact that the spels for each individual are decomposed in several person-year observations has no effect neither on the estimated coefficients nor on the variances of coefficients and their significance (see, for instance, Arjas and Kangas 1992; Singer and Willet 1993) ${ }^{24}$.

In event-history models, contextual variables are treated as any other (timevarying) variable, and the significance tests are equally valid (Blossfeld, Golsch, and Rohwer 2007). As with any other variable, not all individuals in the sample experience all the observed values of these variables. In our sample there are individuals with

${ }^{20}$ This is equivalent to a generalized linear model formulation, but the random component here is more explicit. The relationship between the response and the covariates is not deterministic in the latent-response formulation.

${ }^{21}$ In the data, age is measured in period difference, and as a result individual's age and calendar year are exactly coincident.

${ }^{22}$ Probit or complementary log-log specifications give virtually the same results.

${ }^{23}$ Some individuals entered the risk set above the age of 18 , because the contextual variables included were not available before 1976. Since their time at risk of migration is known (age), this delayed entry into the risk set provides reliable estimates (Rabe-Hesketh and Skrondal 2012, p. 773).

${ }^{24}$ These authors demonstrate that the standard practice in discrete-time event history analysis of treating different time units for each individual as if they were independent is legitimate. They show that the individual's contribution to the likelihood function is analogous to that of continuous time models, since it results from the product of 'time-specific' elements: individuals experiencing events contribute with the probability function, while censored individuals contribute with the survivor function. Finally, these authors also discuss the assumptions implicit in the model, in particular the 'no unobserved heterogeneity' assumption; i.e., that all heterogeneity across individuals is accounted for by variation in the values of the covariates. If this is not the case, the estimates of parameters and confidence intervals may be biased. 
different ages during all the period of observation (1976-2007) and therefore very little collinearity is present between age and the contextual variables included in the analyses (or between contextual variables).

All data used in the analyses are weighted, given that the samples are stratified according to several characteristics. In the Dakar region the first stage of sampling was done by selecting census districts systematically with probability proportional to their estimated size, based on the census of 2002. In each selected district households were stratified according to the presence of return migrants and the existence of household members abroad versus households without migrants. In a final stage, in each of the selected households one or several respondents were selected. The basic aim of stratification in Dakar was to obtain sufficiently large samples of households with migrants (which are a rare group), thus involving their overrepresentation in the sample. In each of the European countries the samples were stratified according to age and sex in order to obtain sufficiently large samples of women and older migrants. By applying weights for the different stratified groups they become proportional in the analyses to their real number in the population (Schoumaker and Mezger 2013) ${ }^{25}$. Yet their use in the multivariate analyses does not alter the substantive results presented here.

\section{Results}

We present the event history analysis results for first migration, distinguishing whether the migration originated in the Dakar region (Table 2, Model 1) or in all of Senegal (Models 2 and 3). As explained before, interviews in Senegal were only conducted in the region of Dakar, while interviews in Europe involved Senegalese of all origins and

\footnotetext{
${ }^{25}$ The computation of weights followed different procedures in the Dakar region with respect to the European samples. Weights for the Dakar region relied on computing sampling probabilities at each stage of sampling (census districts and households, as explained above). The product of sampling probabilities at each stage gave the overall sampling probability. Taking the inverse of the sampling probability gives the inflation factor (i.e., the number of individuals that each individual in the sample represents). These factors were then adjusted taking into account non-response and by trimming the weights.

In Europe, post-stratification weights were constructed in order to match the sex and age group distribution of the Senegalese population resident in each country. Post-stratification weights are equal to the ratio of the percentage of each sex and age group in the population to the percentage in the MAFE survey. Inflating factors were then computed by multiplying the post-stratification weights by the ratio of the population size to the sample size. The population size and structure by age and sex were estimated from different sources (register data in Spain; the Renovated Population Census for France; and based on residence permits and a survey of irregular migrants for Italy).

In the analyses presented here we use the pooled samples for the four countries. Therefore the inflation factors are used, taking into account that the sum of the inflation factors is equal to the sum of the sizes of the populations corresponding to each survey. In a final step, the weights used in the analyses were normalized so that their sum is equal to the sample size (Schoumaker and Mezger 2013).
} 
Baizán \& González-Ferrer: What drives Senegalese migration to Europe?

prior residence. The direction and magnitude of effects are remarkably similar in practically all variables, and suggest that the use of the larger sample does not bias our analyses $^{26}$. However, the Dakar region model results sometimes show less statistical significance, most likely due to the smaller sample size. Consequently, we mainly refer to the results on the all-Senegal data. In Table 3 we present the results of the competing risk analysis for labor migration and other types of migration. Each migration type is very distinctive. In order to take advantage of the complementary nature of their explanations we will integrate our explanation of all results, rather than presenting them successively.

Table 2: Discrete-time event history model estimates of first migration to France, Italy, or Spain, from the Dakar region or all of Senegal

\begin{tabular}{|c|c|c|c|c|c|c|}
\hline & $\begin{array}{l}\text { Dakar region } \\
\text { Model } 1 \\
\text { Odds ratio }\end{array}$ & Sig. & $\begin{array}{l}\text { All of Senegal } \\
\text { Model } 2 \\
\text { Odds ratio }\end{array}$ & Sig. & $\begin{array}{l}\text { All of Senegal } \\
\text { Model } 3 \\
\text { Odds ratio }\end{array}$ & Sig. \\
\hline Age & 1.029 & & 1.303 & $* * *$ & 1.306 & 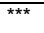 \\
\hline Age squared & 0.994 & $* * \star$ & 0.001 & $* * *$ & 0.995 & $* \star *$ \\
\hline Female & 0.594 & $\star *$ & 0.406 & $\star * *$ & 0.407 & $\star \star *$ \\
\hline \multicolumn{7}{|l|}{ Level of education: Secondary (ref.) } \\
\hline No schooling & 0.288 & $\star * *$ & 0.464 & $\star * *$ & 0.458 & $\star \star * *$ \\
\hline Primary or less & 0.388 & $\star \star \star$ & 0.522 & $\star * *$ & 0.519 & $\star * *$ \\
\hline University & 0.624 & * & 0.725 & & 0.727 & \\
\hline \multicolumn{7}{|l|}{ Occupational Status: Employed (ref.) } \\
\hline Student & 4.223 & $\star * \star$ & 3.915 & *** & 4.039 & $\star \star \star *$ \\
\hline Unemployed & 2.196 & ** & 3.240 & *** & 3.230 & $* * *$ \\
\hline Other inactive & 2.084 & & 2.166 & ** & 2.209 & ** \\
\hline \multicolumn{7}{|c|}{ Socio-economic status (for employed): Skilled manual (ref.) } \\
\hline Higher service sector & 1.549 & & 1.719 & ** & 1.722 & $\star *$ \\
\hline Routine non-manual & 2.068 & ** & 2.483 & *** & 2.482 & $* \star *$ \\
\hline Unskilled manual & 0.632 & & 1.025 & & 1.024 & \\
\hline Agriculture & 2.829 & $* \star \star$ & 3.863 & *** & 3.919 & $\star * *$ \\
\hline Family help (for employed) & 1.171 & & 1.440 & * & 1.463 & $\star *$ \\
\hline Work experience (log) & 1.276 & ** & 1.207 & ** & 1.212 & ** \\
\hline Owns property in Senegal & 1.703 & ** & 1.566 & ** & 1.577 & $\star \star *$ \\
\hline \multicolumn{7}{|l|}{ Partner's location: No partner (ref) } \\
\hline Partner lives in $\mathrm{F}, \mathrm{I}, \mathrm{S}$ & 9.185 & *** & 11.518 & *** & 11.539 & $\star \star \star *$ \\
\hline Partner in Senegal & 0.900 & & 0.962 & & 0.955 & \\
\hline Number of children & 0.881 & * & 0.870 & *** & 0.870 & $\star \star \star *$ \\
\hline Network in F, I, S & 3.930 & $\star * *$ & 4.086 & *** & 3.375 & $\star \star * *$ \\
\hline GDP per capita growth in Senegal & 0.932 & ** & 0.954 & ** & 0.955 & ** \\
\hline Employment growth in F, I,S & 1.019 & & 0.995 & & 0.907 & \\
\hline Employment growth in F, I,S squared & 1.071 & $* *$ & 1.070 & $* * *$ & 1.067 & $\star \star \star *$ \\
\hline Network in F, I, S * Employment growth & & & & & 1.176 & * \\
\hline Person years (unweighted) & 19477 & & 23900 & & 23900 & \\
\hline No. individuals (unweighted) & 1306 & & 1551 & & 1551 & \\
\hline No. of migrations (unweighted) & 365 & & 560 & & 560 & \\
\hline
\end{tabular}

Significance: ${ }^{*} p<0.10,{ }^{* *} p<0.05,{ }^{* * *} p<0.01$. Weighted estimates.

${ }^{26}$ This is also the case for a competing risk analysis of migration types (results not shown). The results of Table 3 refer to migration originating anywhere in Senegal. 


\subsection{Life course and family variables}

First we report on the results concerning several control variables, and subsequently we report on the results concerning several indicators of the variables involved in our hypotheses. Senegalese migration to Europe is strongly stratified by age and sex. The age profile of migrants follows the expected bell shape, peaking around age 28 for both men and women and dropping to its lowest levels after age 40 . This youthful profile of migrants can be even better appreciated in Figure 2's predicted probabilities of first migration by age and sex. The odds of male migration are about $60 \%$ higher than those for females once all migration types are combined (Table 2, Model 2). The Dakar region results suggest that the gender migration gap is smaller in the urban capital context than in the whole of Senegal (Table 2, Models 1 and 2). Men and women migrate for different reasons. Men are about five times more likely than women to migrate as labor migrants, while for other migration types, mainly family-related as discussed below, women have twice the odds of men to migrate (Table 3). That age and sex effects persist even after many other covariates are included is consistent with life course explanations, as well as the age and gender hierarchies existing in Senegalese society. The large gender differentials found for migration to Europe contrast with the much lower differentials prevailing in internal migration and migration within Africa, indicating that migration to Europe is highly selective and subject to a wider range of constraints (Delaunay 1994; Sakho 2013).

Figure 2: Predicted probabilities of first migration from Senegal to France, Italy, and Spain, by age and sex

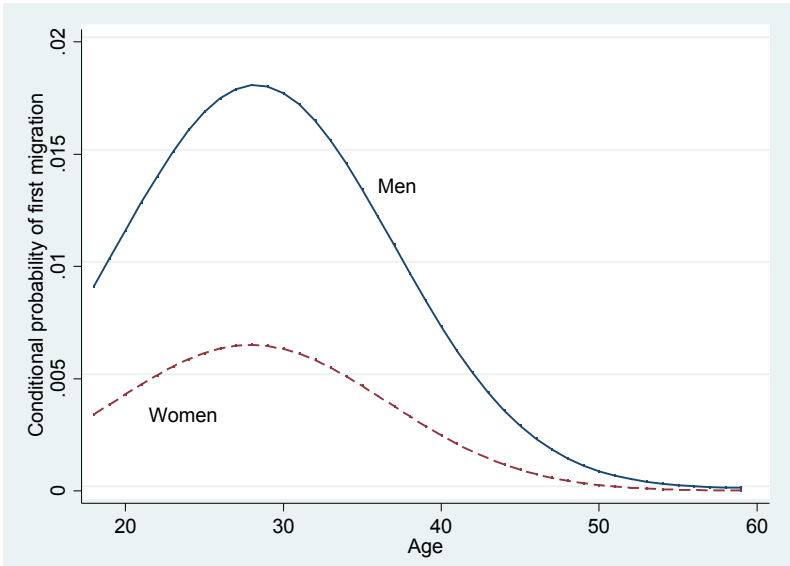

The variables included in the model are age and sex only. Weighted data. 
In order to provide an indication of how the risk of migration has evolved over time we have included Figure 3, which shows the predicted probabilities of first migration from Senegal to France, Italy, and Spain, by time period (4-year periods). The effect of this variable is better captured with periods (a linear predictor provides a positive coefficient of 0.019 with $p<0.01$, while a quadratic effect was not significant). As can be seen, the annual probabilities of migration have increased by about 3.7 times between 1976-1979 and 2000-2003. During the period 1992-1995, migration levels decreased with respect to the previous period, probably in connection with lower labor demand in Europe. In the models included in Tables 2 and 3 the variable 'period' is not included, since when all the other variables are included in the models, period effects become insignificant.

Figure 3: Predicted annual probabilities of first migration from Senegal to France, Italy, and Spain, with $95 \%$ confidence intervals

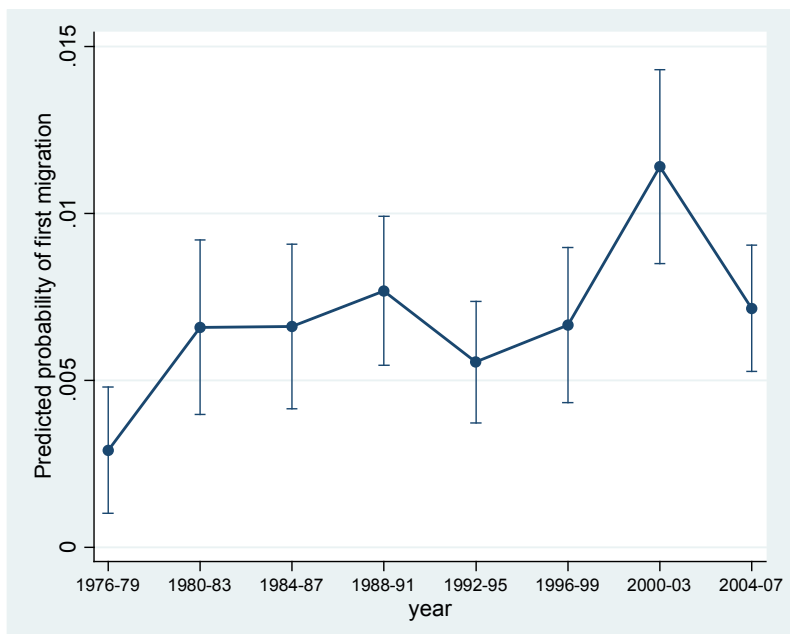

The variables included in the model are year (4-year periods) and age only. Weighted estimates.

The influence of family status depends on the migration type. Being in a partnership (married or unmarried) does not affect labor migration (Table 3) and is consistent with the well-accepted idea of geographical separation of couples in Senegalese society. In this strongly patriarchal family system, conjugal links are not as strong as vertical links (Findley 1997). These results stand in sharp contrast to other migration types, which show a highly significant odds ratio of 2.0 for individuals in a union (Table $3, p<0.01$ ), obviously related to couples' (re)unification after previous 
transnational living arrangements ${ }^{27}$. For all migration types, becoming a parent and the number of children significantly reduce the odds of migration. The extremely high odds ratio for having a partner living in Europe can be explained by marriage-related migration (Table 2, Model 3, $\mathrm{p}<0.01$ ). Bride import is a widespread practice among Senegalese migrants ${ }^{28}$ (Baizan, Beauchemin, and González-Ferrer 2014).

Table 3: Multinomial logistical estimates of discrete-time event history models of first-time migration from Senegal to France, Italy, or Spain, by migration type (Model 4)

\begin{tabular}{|c|c|c|c|c|}
\hline & \multicolumn{2}{|l|}{ Labor migration } & \multicolumn{2}{|c|}{ Other migrations } \\
\hline & Odds ratio & Sig. & Odds ratio & Sig. \\
\hline Age & 1.275 & *** & 1.305 & * \\
\hline Age squared & 0.995 & *** & 0.996 & * \\
\hline Female & 0.208 & *** & 1.958 & $* \star \star$ \\
\hline \multicolumn{5}{|l|}{ Level of education: Secondary (ref.) } \\
\hline No schooling & 0.396 & *** & 0.324 & *** \\
\hline Primary or less & 0.448 & *** & 0.543 & * \\
\hline University & 0.590 & * & 0.915 & \\
\hline \multicolumn{5}{|l|}{ Activity: Employed (ref.) } \\
\hline Student & 1.415 & & 9.469 & $\star \star \star *$ \\
\hline Unemployed & 3.301 & *** & 1.947 & \\
\hline Other inactive & 1.522 & & 2.700 & \\
\hline \multicolumn{5}{|c|}{ Socio-economic status (for the employed): Skilled manual (ref.) } \\
\hline Higher service sector & 1.648 & * & 1.699 & \\
\hline Routine non-manual & 2.990 & *** & 1.432 & \\
\hline Unskilled manual & 1.210 & & 0.814 & \\
\hline Agriculture & 3.529 & 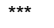 & 5.501 & 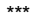 \\
\hline Family help (for employed) & 1.497 & * & 1.294 & \\
\hline Work experience (log) & 1.276 & ** & 0.951 & \\
\hline Owns property in Senegal & 1.715 & ** & 1.089 & \\
\hline \multicolumn{5}{|l|}{ Partnership status: No partner (ref) } \\
\hline In partnership & 1.332 & & 2.006 & 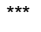 \\
\hline Number of children & 0.844 & *** & 0.790 & *** \\
\hline Network in F, I, S & 3.133 & *** & 4.344 & $* \star \star$ \\
\hline GDP per capita growth in Senegal & 0.942 & ** & 0.954 & \\
\hline Employment growth in $\mathrm{F}, \mathrm{I}, \mathrm{S}$ & 0.862 & * & 1.060 & \\
\hline Employment growth in $F, I, S$ squared & 1.088 & *** & 1.025 & \\
\hline Network in $F, I, S{ }^{*}$ Employment growth & 1.236 & ** & 1.009 & \\
\hline Person years (unweighted) & 23679 & & 23561 & \\
\hline No. individuals (unweighted) & 1551 & & 1551 & \\
\hline No. of migrations (unweighted) & 339 & & 221 & \\
\hline
\end{tabular}

Significance: ${ }^{*} p<0.10,{ }^{\star *} p<0.05,{ }^{* \star} p<0.01$. Weighted estimates.

${ }^{27}$ Children generally accompany their mothers in this type of migration (González-Ferrer, Baizan, and Beauchemin 2012).

${ }^{28}$ More detailed analyses of family-related migration using MAFE data can be found in Baizan, Beauchemin, and González-Ferrer (2014); Beauchemin et al. (2015): and in Mazzucato et al. (2015). 
In all models, education is strongly and significantly influential, and its effects follow an inverted $\mathrm{J}$ shape ${ }^{29}$. As expected, individuals with no schooling have very low levels of migration, their odds are nearly $60 \%$ lower than those with some secondary education, and individuals with some primary schooling have only slightly higher odds. Considering that the Senegalese population is characterized by very low levels of education (according to MAFE data, more than a third have never attended school) and high illiteracy rates, education contributes powerfully to lower overall levels of migration. Low education curtails employment chances in the highly competitive European labor markets, where a minimum of education is expected, even for low-level jobs. Unexpectedly, the odds of university-educated individuals to migrate are somewhat lower than those of the secondary-educated, although this difference is not consistently significant. A likely explanation is that the highly educated enjoy better employment probabilities and possibilities in both Europe and Senegal, and confront steeper downward mobility in European labor markets.

\subsection{Economic Insecurity Hypothesis}

Migration is also influenced by other human capital and socio-economic variables. Despite the difficulties of transferring human capital internationally, work experience clearly increases the probability of labor migration, while having no effect for other migration types (Table 3). This variable could also be a proxy for the accumulation of financial resources needed to migrate. Also, socio-economic status is a direct indicator of financial resources. Measured only for the employed, socio-economic status follows the expected inverted U-shape. For labor migration (Table 3), individuals employed in routine non-manual occupations have a relative odds nearly 3 times higher than manual employees (no significant differences between skilled and unskilled workers were found), suggesting that migration may not be an option available to the poor. Higher service jobs have an odds $60 \%$ higher than skilled manual jobs, but have much lower odds than 'routine non-manual' jobs (Table 3). This finding is consistent with the idea that quitting higher service sector jobs (because of migration) involves a higher opportunity cost than quitting a routine non-manual job. In addition, higher service sector jobs are least likely to be affected by informality and insecurity, and their lower probabilities of migration are consistent with our 'economic insecurity' hypothesis.

The major exception to the expected pattern of migration by job status is agricultural workers, who have more than triple the odds of migration of skilled manual workers for labor migration (and 5.5 times the odds in the case of non-labor migration).

${ }^{29}$ An alternative specification of educational level as a continuous variable (years of schooling) yields a significant, strong positive effect. However, the addition of a square term was not significant. 
Profound agricultural crises and high levels of insecurity in the agricultural sector during the period of interest are likely to be responsible for encouraging agricultural workers to consider migration in order to diversify resources and earn income, as suggested by our 'economic insecurity' hypothesis. At the same time, given the very low incomes of agricultural workers, this result questions the hypothesis that poverty and the cost of migration largely restrict international migration. It is likely that family and community resources (including migrant networks) have contributed decisively to implementing migration in such cases.

Owning property in Senegal also raises the likelihood of labor migration, but is not significant for other migration types (Table 3). Owning physical capital in the form of land, a dwelling, or a business is likely to be related to reduced financial constraints on migration. However, as emphasized by institutional economics, it can also indicate a higher demand for financial capital, which, given the difficulties in accessing credit in Senegal, can then be satisfied through international migration.

Other results regarding the individual's socio-economic position support perspectives that emphasize the role of economic insecurity and the need to diversify income sources. For labor migration, the unemployed have an odds of migration more than triple the migration odds of the employed. Unemployment status is not significant for other migration types. The distinction between unemployment and inactivity may not be clear-cut in a developing country, considering as well that only the 'main' occupation is reported. The distinction between employment and inactivity can be especially vague for women, who may underreport economic activities performed in addition to household work. Therefore, it is not surprising to find that the migration odds of the 'other inactive' are twice as high as for the employed (Table 2, Model 2: but in Table 3, results are not significant). Low opportunity cost can help explain migration decisions of the unemployed, or of individuals with low productivity activities who can easily be substituted by other household members. This may also explain the high migration odds of family helpers (including domestic servants), who tend to work as part of the informal economy and are affected by high levels of insecurity. Finally, signaling student migration, students have an extremely high odds ratio of other types of migration compared to the employed (Table 3).

Each percentage point increase in per capita Gross Domestic Product lowers the predicted probability of labor migration to Europe by about $6 \%(\mathrm{p}<.05)$, while having no significant effect on other migration types (Table 3). Considering that Senegal's GDP growth was negative during most of the 1980s and 1990s, this indicator provides evidence that deterioration of living conditions and increased economic risk lead to migration. This strong effect of GDP change is net of other individual variables that mediate the effects of economic crises, such as unemployment and job status. Furthermore, the expected effect of GDP change may be partially counterbalanced by 
parallel change in the resources available to individuals, thus influencing the capacity to pay for migration, in particular among the poorest.

\subsection{Social Capital Hypothesis}

As is the case for financial resources, individuals are more likely to migrate when they possess a certain level of social capital. Having a network in Europe substantially and significantly increases the odds of migration throughout the models (Table 2 and 3). Having friends or relatives in Europe (not including partners) more than triples one's likelihood to migrate for labor reasons, with respect to individuals without them. ${ }^{30}$. Networks are even more essential in the case of family reunification and family formation, and the results confirm this (Table 3). When interpreting the results, it should be born in mind that Senegalese kin and friendship networks in Europe have greatly expanded since the early 1980s, in parallel with the expansion of Senegalese communities abroad, which then leads to a multiplier effect on migration rates.

\subsection{Labor Demand Hypothesis}

Our indicator of labor demand, the rate of employment growth in France, Italy, and Spain, suggests that Senegalese migration responds to employment opportunities in Europe. This effect does not follow a linear pattern. Instead, migration is boosted when labor demand is sufficiently strong (above $2 \%$ ), while it stagnates below that level. This suggests that migrant labor is attracted only once European labor markets have first mobilized their own pool of unemployed (to a certain extent, since substantial unemployment levels persist even in periods of economic expansion). 'Employment growth squared' has a substantial effect for labor migration, as the odds indicate a $9 \%$ increase for each percentage point increase in employment $(\mathrm{p}<0.01)$. As expected, no significant effects are found for other migration types (Table 3 ). These results support the key prediction of the segmented labor market theory, i.e., that labor demand is a crucial factor driving migration.

\footnotetext{
${ }^{30}$ For the sake of simplicity, we model network availability as a dummy variable here. Alternative specifications of network availability, such as the logarithm of the number of network members or different network member dummies, also provide strong positive effects (results not shown, but available upon request).
} 


\subsection{Hypothesis of Interaction between Labor Demand and Social Capital}

Earlier in this paper, we proposed that this labor demand might go largely unnoticed if social capital abroad were not available to link employment opportunities and potential migrants. In order to test this hypothesis we have included an interaction term of employment growth and network availability. For labor migration, the interaction term is highly significant (Table $3, \mathrm{p}<.05$ ). Figure 4 (based on Table 2, Model 3 ) shows that the migration probabilities of individuals with and without networks differ significantly. Furthermore, in a context of employment growth of at least $2 \%$, individuals with access to networks see substantial increases in their migration probabilities as compared to individuals without networks. This evidence supports the idea that social capital is key for accessing employment opportunities for Senegalese in Europe.

Figure 4: Predicted probability of first migration to France, Italy, and Spain, by employment growth in France, Italy, and Spain and network availability, with $95 \%$ confidence intervals

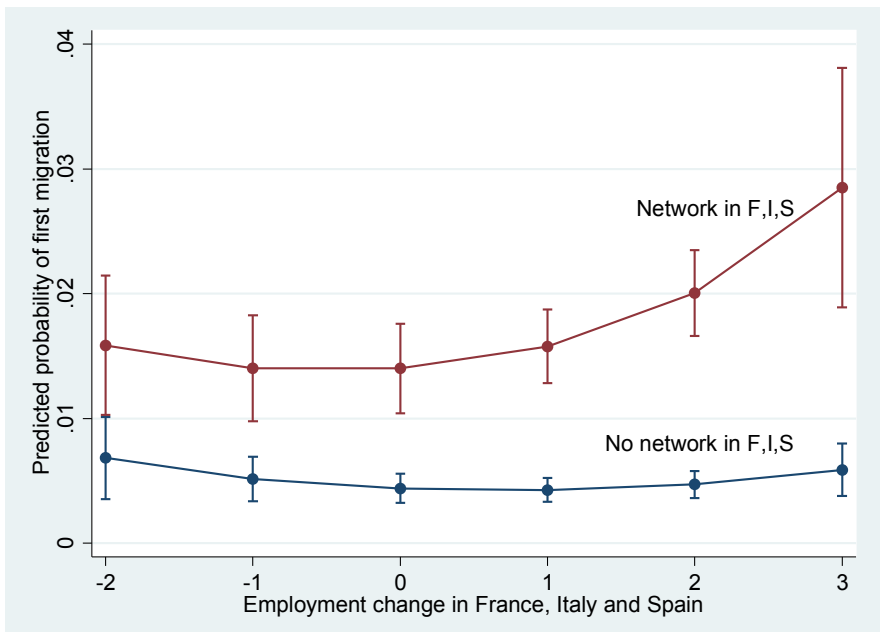

The variables included in the model are those of Model 3 (Table 2); variables other than network availability and employment growth are set at their mean values. Weighted data. 


\section{Conclusions}

Despite the growing importance and potential of migration from Sub-Saharan Africa to Europe, few quantitative studies have examined its socio-economic determinants. This paper contributes to the understanding of migration movements from Senegal to France, Italy, and Spain by examining how both individual and contextual factors influence individual migration behavior. Particular attention has been paid to the link between micro-level factors and contextual factors, both at origin and in Europe. From the 1980s to the mid 2000s, the Senegalese economy and society experienced profound changes that simultaneously incorporated it in the rest of the world and marginalized it. The surge in international migration during this period is part of these changes.

In this paper we proposed and empirically tested four hypotheses that specify the contextual- and individual-level conditions that have lead to migration between Senegal and Europe. These theoretical propositions are closely interlinked and are based on mutually reinforcing factors. Together they provide a coherent account of the development of a migration system that integrates several existing approaches to international migration. Given the mechanisms involved, we believe these hypotheses have a wide applicability when explaining migration from developing to developed countries. Our empirical analyses provided support for our four hypotheses, although not all dimensions of the hypotheses could be tested due to data limitations.

The results reported here concerning both individual socioeconomic indicators and macroeconomic growth are consistent with our first hypothesis (Economic Uncertainty Hypothesis), and more generally with institutional perspectives emphasizing the role of economic uncertainty and the need to diversify resources. Individual financial resources show a complex relationship with migration, and broadly support the idea that a minimum of resources is needed for migration. However, individuals working in the primary sector where poverty is pervasive also show very high levels of migration, which suggests the specific role of resources in the context of peasant households. Education is particularly powerful in explaining Senegalese migration. Individuals with a primary education or less display very low levels of migration. The expansion of education may increase individual migration capabilities. Education helps individuals overcome social and economic barriers to migration, increases social status and consumption aspirations, and facilitates access to employment opportunities at destination.

Since the mid-1970s, Senegal has experienced a long period in which economic and human development has stagnated or deteriorated. In such a context, families and individuals have strategized to counter the deterioration of living conditions and avoid downward social mobility. One of these strategies, international migration, involved the mobilization of individuals' social capital resources to gain access to jobs abroad. This 
strategy was made feasible by the expansion of employment opportunities in particular sectors and places in Europe from the mid-1980s. This expansion resulted from the processes of labor market deregulation, the growth of the underground economy in the south of Europe, and strategies of businesses to increase competitiveness. Our results show strong effects of employment growth in Europe on the likelihood of migration, particularly during periods of rapid economic expansion, providing support for our Labor Demand Hypothesis. We have highlighted the specific functioning of the destination labor market in order to explain why availability of social networks abroad is needed to access such labor demand. Having acquaintances or relatives in Europe more than triples the odds of labor migration (quadruples the odds for other migration types) compared to individuals without such connections (Social Capital Hypothesis). These sharp differences in migration probability between individuals with and without networks abroad demonstrate how important social capital is in channeling and selecting candidates in a very socially segmented society. But the availability of social capital per se has a small impact on migration probability. Our analyses have shown that a conjunction of periods of strong labor demand with availability of personal networks in Europe is needed to create a boosting effect on migration probabilities from Senegal to Europe (Interaction Between Labor Demand and Social Capital Hypothesis). Overall, our findings provide theoretical and empirical support for the several propositions that specify the conditions that have been key in the development of the migration system between Senegal and Europe. By the same token, a change in the direction of the mechanisms involved could undermine further development of the migration stream; for instance, as the consequence of a drop in labor demand in Europe or of an improvement in economic security at origin.

Although this paper contributes to exploring the connection between the different levels and locations that explain Senegalese migration to Europe, it has certain limitations. First, there is limited availability of household- and family-level indicators, which prevents a clearer analysis of how household economic situation and migration are linked. Particularly useful would be information concerning the household decisionmaking process. Also, the dearth of available macro variables, including policy-related variables, prevents a more nuanced analysis of contextual effects in both Senegal and Europe. Our results concerning the key importance of labor market conditions in destination countries point to the need for more detailed analysis of the occupations, job conditions, and other labor market characteristics of each European destination. 
Baizán \& González-Ferrer: What drives Senegalese migration to Europe?

\section{Acknowledgments}

The work has benefitted from useful suggestions and discussions with Mathew Creighton, Mao-Mei Liu, and the participants of the workshop 'The Decision to Emigrate. Agent-Based Modeling of International Migration', Max-Planck Institute for Demographic Research, Rostock, 25-27 September 2013. We also thank two anonymous reviewers and the journal editor for their comments and useful suggestions.

The research reported here has been funded by the Spanish Ministry of Economy and Competitivity, National Program of Research and Development (CSO2012-37920). 


\section{References}

Adepoju, A. (2004). Trends in international migration in and from Africa. In: Massey, D. and Taylor, E. (eds.). International migration: Prospects and policies in a global market. New York: Oxford University Press: 59-76. doi:10.1093/ 0199269009.003.0004.

Agence Nationale de la Statistique et de la Démographie (ANSD) (1995). Rapport national d'Enquête sur les migrations et l'urbanisation au Sénégal (EMUS) 1993. Direction de la Prévision et de la Statistique et le Réseau Migration et Urbanisation en Afrique de l'Ouest. Dakar: Ministère de l'Economie et des Finances, Senegal.

Agence Nationale de la Statistique et de la Démographie (ANSD) (2004). Rapport de synthèse de la deuxième Enquête sénégalaise auprès des ménages (ESAM II, 2001). Dakar: Ministère de l'Economie et des Finances, Senegal.

Agence Nationale de la Statistique et de la Démographie (ANSD) (2006). Rapport national de présentation des résultats du troisième Recensement général de la population et de l'habitat en 2002. Dakar: Ministère de l'Économie et des Finances, Senegal.

Ambrosini, M. (2001). The role of immigrants in the Italian labour market. International Migration 39(3): 61-83. doi:10.1111/1468-2435.00156.

Antoine, P., Bocquier, P., Fall, A.S., Guisse, Y.M., and Nanitelamio, J. (1995). Les familles dakaroises face à la crise. Dakar: IFAN/ORSTOM/CEPED. http://www.documentation.ird.fr/hor/fdi:010004560.

Arjas, E. and Kangas, P. (1992). A discrete-time method for the analysis of event histories. In: Trussel, J., Hankinson, R., and Tilton, J. (eds.) Demographic applications of event history analysis. Oxford: Clarendon. 253-266.

Auriat, N. (1996). Les défaillances de la mémoire humaine: Aspects cognitifs des enquêtes rétrospectives. Travaux et Documents de l'INED 136. Paris: Presses Universitaires de France.

Azam, J-P. (2004). Poverty and growth in the WAEMU after the 1994 devaluation. Journal of African Economies 13(4): 536-562. doi:10.1093/jae/ejh029.

Baizan, P., Beauchemin, C., and González-Ferrer, A. (2014). An origin and destination perspective on family reunification: The case of Senegalese couples. European Journal of Population 30(1): 65-87. doi:10.1007/s10680-013-9305-6. 
Baizán \& González-Ferrer: What drives Senegalese migration to Europe?

Banque centrale des États de l'Afrique de l'Ouest (2008). Tableaux synoptiques des montants de transferts de fonds au Sénégal. Dakar: BCEAO.

Banque Mondiale (2007). Sénégal: A la recherche de l'emploi - Le chemin vers la prospérité. Mémorandum économique sur le pays (en deux volumes), Volume I et II : Annexes, Banque mondiale, région Afrique.

Barbieri, P. (1997). Non c'è rete senza nodi: Il ruolo del capitale sociale nel prcesso di incontro fra domanda e offerta di lavoro. Stato e Mercato 49: 67-110. doi: $10.1425 / 390$.

Barrett, C.B., Reardon, T., and Webb, P. (2001). Nonfarm income diversification and household livelihood strategies in rural Africa: Concepts, dynamics, and policy implications. Food Policy 26(4): 315-331. doi:10.1016/S0306-9192(01)000148.

Beauchemin, C. and González-Ferrer, A. (2011). Sampling international migrants with origin-based snowballing method: New evidence on biases and limitations. Demographic Research 25(3): 103-134. doi:10.4054/DemRes.2011.25.3.

Beauchemin, C. (2012). Migrations between Africa and Europe (MAFE): Rationale for a survey design. MAFE Methodological Note 5. Paris: MAFE.

Beauchemin, C. (2014). A manifesto for quantitative multi-sited approaches to international migration. International Migration Review 48(4): 921-938. doi:10.1111/imre.12157.

Beauchemin, C., Nappa, J., Schoumaker, B., Baizan, P., González-Ferrer, A., Caarls, K., and Mazzucato, V. (2015). Reunifying versus living apart together across borders: A comparative analysis of sub-Saharan migration to Europe. International Migration Review 49(1): 173-199. doi:10.1111/imre.12155.

Blossfeld, H.-P., Golsch, K., and Rohwer, G. (2007). Event history analysis with Stata. New York: Psychology Press.

Bocquier, P. (1996). Insertion et mobilité professionnelles à Dakar. Paris: ORSTOM.

Boone, C. (1991). Politics under the spectre of deindustrialization: 'Structural adjustment' in practice. In: Delgado, C.L., and Jammeh, S. (eds.). The political economy of Senegal under structural adjustment. New York: Praeger.

Bruzzone, T., Fall, P.D., Tall, M., and Gueye, C. (2006). Le milieu sénégalais et l'action transnationale des migrants. Rome: Centro Studi di Politica Internazionale. 
Castagnone, E., Sakho, P., Nazio, T., Schoumaker, B., and Rakotonarivo, N. (2013). African migrants at work. Patterns of labour market integration in Europe, transnational economic participation and economic re-integration of migrants in origin countries. The case of Senegal. MAFE Working Paper 29. Paris: MAFE.

Castles, S. and Miller, M.J. (2009). The age of migration: International population movements in the modern world. $4^{\text {th }}$ ed. Basingstoke: Palgrave Macmillan.

Collier, P. and Gunning, J.W. (1999). Explaining African economic performance. Journal of Economic Literature 37(1): 64-111. doi:10.1257/jel.37.1.64.

Courgeau, D. (1992). Impact of response errors on event history analysis. Population: An English Selection 4: 97-110.

David, R. (1995). Changing places: Women, resource management and migration in the Sahel. London: SOS Sahel.

de Haan, A. (1999). Livelihoods and poverty: The role of migration - A critical review of the migration literature. Journal of Development Studies 36(2): 1-47. doi:10.1080/00220389908422619.

de Haas, H. (2010). The internal dynamics of migration processes: A theoretical inquiry. Journal of Ethnic and Migration Studies 36(10): 1587-1617. doi:10.1080/1369183X.2010.489361.

Delaunay, V. (1994). L'entrée en vie féconde: Expression démographique des mutations socio-économiques d'un milieu rural sénégalais. Paris: CEPED. http://www.documentation.ird.fr/hor/fdi:41324.

Development Research Centre on Migration, Globalisation and Poverty, DRC. (2007). Global Migrant Origin Database, Updated March 2007. http://www.migrationdrc.org/

Diop, A.-B. (1985). La famille wolof: Tradition et changement. Paris: Karthala.

Duruflé, G. (1988). L'ajustement structurel en Afrique (Sénégal, Côte d'Ivoire, Madagascar). Paris: Karthala.

Ellis, E. (2000). Rural livelihoods and diversity in developing countries. Oxford: Oxford University Press.

Erikson, R. and Goldthorpe, J.H. (1992). The constant flux: A study of class mobility in industrial societies. Oxford: Clarendon.

Fatton, R. (1986). Clientelism and patronage in Senegal. African Studies Review 29(4): 61-78. doi: $10.2307 / 524006$. 
Baizán \& González-Ferrer: What drives Senegalese migration to Europe?

Findley, S. and Sow, S. (1998). From season to season: Agriculture, poverty and migration in the Senegal River Valley. In: Appleyard, R. (ed.). Emigration dynamics in developing countries. Vol. 1: Sub-Saharan Africa. Aldershot: Ashgate: $69-144$.

Findley, S. (1997). Migration and family interactions in Africa. In: Adepoju, A. (ed.). Family, population and development in Africa. London: Zed Books: 109-138.

Gallie, D. and Paugam, S. (2000). The experience of unemployment in Europe: The debate. In: Gallie, D. and Paugam, S. (eds.). Welfare regimes and the experience of unemployment in Europe. Oxford: Oxford University Press.

Galvan, D. (2001). Political turnover and social change in Senegal. Journal of Democracy 12(3): 51-62. doi:10.1353/jod.2001.0047.

Garip, F. (2008). Social capital and migration: How do similar resources lead to divergent outcomes? Demography 45(3):591-617. doi:10.1353/dem.0.0016.

Granovetter, M. (2005). The impact of social structure on economic outcomes. Journal of Economic Perspectives 19(1): 33-50. doi:10.1257/0895330053147958.

González-Ferrer, A., Baizan, P., and Beauchemin, C. (2012). Child-parents separation among Senegalese migrants to Europe: Migration strategies or cultural arrangements? The Annals of the American Academy of Political and Social Science 643(1): 106-133. doi:10.1177/0002716212444846.

González-Ferrer, A., Baizan, P., Beauchemin, C., Kraus, E., Schoumaker, B., and Black, R. (2014). Distance, transnational arrangements, and return decisions of Senegalese, Ghanaian, and Congolese migrants. International Migration Review 48(4): 939-971. doi:10.1111/imre.12148.

Grillo, R. and Mazzucato, V. (2008). Africa-Europe: A double engagement. Journal of Ethnic and Migration Studies 34(2): 175-198. doi:10.1080/ 13691830701823830.

Guilmoto, C.Z. (1998). Institutions and migrations: Short-term versus long-term moves in rural West Africa. Population Studies 52(1): 85-103. doi:10.1080/ 0032472031000150196.

Hatton, T. and Williamson, J. (2003). Demographic and economic pressure on emigration out of Africa. Scandinavian Journal of Economics 105(3): 465-486. doi:10.1111/1467-9442.t01-2-00008.

Heath, A. and Cheung, S.Y. (2007). The comparative study of ethnic minority disadvantage. In: Heath, A. and Cheung, S.Y. (eds.). Unequal chances: Ethnic 
minorities in Western labour markets. Oxford: Oxford University Press. doi:10.5871/bacad/9780197263860.003.0001.

International Labor Office (2002). Women and men in the informal economy: A statistical picture. Geneva: International Labor Office.

Kothari, U. (2002). Migration and chronic poverty. Chronic Poverty Research Centre Working Paper no. 16. Manchester: Institute for Development Policy and Management, University of Manchester. doi:10.2139/ssrn.1754530.

Krissman, F. (2005). Sin coyote ni patrón: Why the "migrant network" fails to explain international migration. International Migration Review 39(1): 4-44. doi:10.1111/j.1747-7379.2005.tb00254.x.

Krokfors, C. (1995). Poverty, environmental stress and culture as factors in African migrations. In: Baker, J. and Akin Aina, T. (eds.). The migration experience in Africa. Uppsala: Nordiska Afrikainstitutet: 54-64.

Lalou, R. and Ndione, B. (2005). Stratégies migratoires et recomposition des solidarités dans un contexte de crise: L'exemple du Sénégal urbain. In: Vignikin, K. and Vimard, P. (eds.). Familles au nord, familles au sud. Louvain-la-Neuve: Academia-Bruylant: 449-479.

Lindstrom, D.P., Hadley, C., and Belachew, T. (2012). The role of migration and income diversification in protecting households from food insecurity in southwest Ethiopia. 2012 Annual meeting of the Population Association of America.

Liu, M.-M. (2013). Migrant networks and international migration: Testing weak ties. Demography 50(4): 1243-1277. doi:10.1007/s13524-013-0213-5.

Lucas, R. (2006). Migration and economic development in Africa: A review of evidence. Journal of African Economies 15(2): 337-395. doi:10.1093/ jafeco/ej1032.

Martin, P.L. (1993). Trade and migration: NAFTA and agriculture. Vol. 30. Washington, D.C.: Institute for International Economics.

Martin, P. and Widgren, J. (1996). International migration: A global challenge. Population Bulletin 51(1): 1-47.

Massey, D.S. (1990). Social structure, household strategies, and the cumulative causation of migration. Population Index 56(1): 3-26. doi:10.2307/3644186. 
Baizán \& González-Ferrer: What drives Senegalese migration to Europe?

Massey, D.S., Arango, J., Hugo, G., Kouaouci, A., Pellegrino, A., and Taylor, J.E. (1998). Worlds in motion: Understanding international migration at the end of the millennium. Oxford: Clarendon.

Mayer, K.U. (2001). The paradox of global social change and national path dependencies: Life course patterns in advanced societies. In: Woodward, A. and Kohli, M. (eds.). Inclusions and exclusions in European societies. New York: Routledge: 89-110.

Mazzucato, V., Schans, D., Caarls, K., and Beauchemin, C. (2015). Transnational families between Africa and Europe. International Migration Review 49(1): 142-172. doi:10.1111/imre.12153.

Mezger, C. and Beauchemin, C. (2010). The role of international migration experience for investment at home: The case of Senegal. MAFE Working Paper 12. Paris: MAFE.

Mezger C. and González-Ferrer, A. (2013). The ImPol Database: A new tool to measure immigration policies in France, Italy and Spain since the 1960s. MAFE Working Paper 34. http://mafeproject.site.ined.fr/en/publications/working papers/

Mulder, C.H. (1993). Migration dynamics: A life course approach. Amsterdam: Thesis Publishers.

Munshi, K. (2003). Networks in the modern economy: Mexican migrants in the U.S. labor market. The Quarterly Journal of Economics 118(2): 549-599. doi:10.1162/003355303321675455.

Obucina, O. (2013). Occupational trajectories and occupational cost among Senegalese immigrants in Europe. Demographic Research 28(19): 547-580. doi:10.4054/DemRes.2013.28.19.

OECD (2010). Annual Labour Force Statistics database. http://stats.oecd.org/index.aspx (accessed November 11, 2010).

Piore, M.J. (1979). Birds of passage: Migrant labor and industrial societies. New York: Cambridge University Press. doi:10.1017/CBO9780511572210.

Pison, G., Hill, K., Cohen, B., and Foote, K. (1997). Croissances et répartition de la population: Migrations. In: Les changements démographiques au Sénégal, Travaux et Document de l'INED 138: 31-38.

Poiret, C. (1996). Familles africaines en France. Paris: L'Harmattan. 
Polavieja, J.G. (2003). Estables y precarios: Desregulación laboral y estratificación social en España. Madrid: Centro de Investigaciones Sociológicas.

Portes, A. (1997). Neoliberalism and the sociology of development: Emerging trends and unanticipated facts. Population and Development Review 23(2): 229-259. doi: $10.2307 / 2137545$.

Portes, A. (2010). Migration and social change: Some conceptual reflections. Journal of Ethnic and Migration Studies 36(10): 1537-1563. doi:10.1080/ 1369183X.2010.489370.

Portes, A. and Bach, R.L. (1985). Latin journey: Cuban and Mexican immigrants in the United States. Berkeley: University of California Press.

Portes, A. and Rumbaut, R.G. (2001). Legacies: The story of the immigrant second generation. Berkeley: University of California Press and Russell Sage Foundation.

Rabe-Hesketh, S. and Skrondal, A. (2012). Multilevel and longitudinal modeling using Stata. College Station: Stata Press.

Reyneri, E. (2003). Immigration and the underground economy in new receiving South European countries: Manifold negative effects, manifold deep-rooted causes. International Review of Sociology 13(1): 117-143. doi:10.1080/ 0390670032000087023.

Reyneri, E. and Fullin, G. (2011). Labour market penalties of new immigrants in new and old receiving West European countries. International Migration 49(1): 3157. doi:10.1111/j.1468-2435.2009.00593.x.

Robin, N., Lalou, R., and Ndiaye, M. (1999). Facteurs d'attraction et de répulsion à l'origine des flux migratoires internationaux. Rapport national Sénégal. Brussels: Commission européenne.

Rosenfeld, M.J. and Tienda, M. (1999). Mexican immigration, occupational niches, and labor-market competition: Evidence from Los Angeles, Chicago, and Atlanta, 1970 to 1990. In: Bean, F.D. and Bell-Rose, S. (eds.). Immigration and opportunity: Race, ethnicity, and employment in the United States. New York: Russell Sage Foundation: 31-63.

Sakho, P. (2013). New patterns of migration between Senegal and Europe (France, Italy and Spain). MAFE Working Paper 21. Paris: MAFE. 
Baizán \& González-Ferrer: What drives Senegalese migration to Europe?

Sassen, S. (1988). The mobility of labor and capital: A study in international investment and labor flow. Cambridge: Cambridge University Press. doi:10.1017/ CBO9780511598296.

Schoumaker, B. and Mezger, C. (2013) Sampling and computation weights in the MAFE Surveys. MAFE Methodological Note 6. Paris: MAFE.

Scoones, I. (1998). Sustainable rural livelihoods: A framework for analysis. IDS Working Paper 72. Brighton: IDS.

Singer, J. and Willett, J. (1993). It's about time: Using discrete-time analysis to study duration and the timing of events. Journal of Educational Statistics 18(2): 155195. doi:10.2307/1165085.

Stark, O. (1991). The migration of labor. Oxford: Blackwell.

Thioub, I., Diop, M.-C., and Boone, C. (1998). Economic liberalization in Senegal: Shifting politics of indigenous business interests. African Studies Review 41(2): 63-89. doi:10.2307/524827.

Toma, S. and Vause, S. (2011). Migrant networks and gender in Congolese and Senegalese international migration. MAFE Working paper. Paris: MAFE.

United Nations Development Programme (2009). Overcoming barriers: Human mobility and development. Human development report 2009. New York: UNDP.

United Nations Office on Drugs and Crime (2006). Organized crime and irregular migration from Africa to Europe. Vienna: UNODC. www.unodc.org/pdf/research/Migration_Africa.pdf.

van Dalen, H.P., Groenewold, G., and Schoorl, J.J. (2005). Out of Africa: What drives the pressure to emigrate? Journal of Population Economics 18(4): 741-778. doi:10.1007/s00148-005-0003-5.

Villarreal, A. and Blanchard, S. (2013). How job characteristics affect international migration: The role of informality in Mexico. Demography 50(2): 751-775. doi:10.1007/s13524-012-0153-5.

Weissman, S.R. (1990). Structural adjustment in Africa: Insights from the experiences of Ghana and Senegal. World Development 18(12): 1621-1634. doi:10.1016/ 0305-750X(90)90059-7.

World Bank (2008). Migration and Remittances Factbook. Washington, D.C.: World Bank. www.worldbank.org/prospects/migrationandremittances. 
World Bank (2012). World Development Indicators. Washington, D.C.: World Bank. http://data.worldbank.org. 
Baizán \& González-Ferrer: What drives Senegalese migration to Europe? 